\title{
Advances of a pilot study on gasification of Saccharum Spontaneum to produce electricity in Panama
}

\author{
Orlando Aguilar ${ }^{1, *}$, Daniel Navarro², Yubrany González ${ }^{2}$, Elvis $_{\text {García }}^{2}$, Heidy Camargo ${ }^{2}$, and Orlando Aguilar Jr. ${ }^{2}$ \\ ${ }^{1}$ Universidad Tecnológica de Panamá, Research Director and Professor at Mechanical Engineering Department, Panamá, Panamá. \\ Research Group on Renewable Energy and Environment (GIERA)-UTP, Panama. \\ ${ }^{2}$ Universidad Tecnológica de Panamá. Mechanical Engineering Department, Panamá, Panamá. GIERA Research Group-UTP.
}

\begin{abstract}
Saccharum spontaneum, known locally as "Paja Canalera", is a non-native herbaceous species of Panamanian flora, it is invasive and can spread rapidly, even in critical environmental conditions. In the dry season, it is the object of fires of plant mass affecting other species of flora, fauna and communities. This study focuses on assessing the use of the species as a biomasic material for energy production through the gasification technique. Samples of the material present in the Panama Canal Hydrographic Basin (CHCP) were conducted, where there are approximately 6,932 hectares covered by that species. A thermophysical and energetic characterization of the species was carried out, and the use of said plant species is considered as a renewable energy resource with the potential to be converted into gaseous fuel (syngas) by means of the gasification technique and its subsequent generation of electrical energy. Based on the available Biomass, results indicate an energy potential of $536.5 \mathrm{GWh}$. Tests of various treatments were carried out based on the physical properties of the biomass and tested with various volumetric air flows in order to find the most efficient form of gasification of $S$. spontaneum, based on the chemical composition of the resulting gas.
\end{abstract}

\section{Introduction}

This research project is originated from the observation of the growing energy demand worldwide and the negative impact that this causes on global warming of the planet when that demand is supplied using fossil fuels. An alternative of positive impact is to meet the energy demand with renewable energy sources. Panama does not escape from this reality, the need to diversify the national energy matrix is imperative, since the consumption of hydrocarbons is very expensive for the country.

In recent years, the research and development of technologies for using renewable energy sources, has made significant progress, such as photovoltaic solar energy, wind energy, biomass and ocean energies, among others. However, none of these technologies alone could completely displace fossil fuel use; so, a possible solution is the diversification of the energy matrix, incorporating in this greater variety of renewable resources and in greater quantity. Biomass technology is considered capable of largely displacing the use of fossil fuels $[1,2]$. From the energy point of view, biomass includes all material derived from living beings (plants or animals), which can be used directly as fuel by combustion, or that can be processed by thermochemical or biological processes to obtain chemical products or refined fuels (solid, liquid or gas) [3-5]. Biological resources can be used sustainably, regenerating the sources in relatively short cycles. Compared to fossil fuels, biomass has advantages for the generation of electrical energy, such as neutral balance in carbon emissions, low emissions of sulfur oxides, nitrogen oxides, as well as heavy metals and unburned hydrocarbons. Because of these advantages, the use of biomass is becoming an attractive solution for the mitigation of greenhouse gases in the world [6]. Another important advantage of biomass to produce fuels or electrical energy is that when using residues with low or no food value, such as forest residues, agricultural and agroindustrial residues, herbaceous weeds and lignocellulosic energy crops of rapid growth, global food security isn't negatively impacted $[4,7]$.

Lignocellulosic biomass is a matter of plant origin, mainly composed of cellulose, hemicellulose and lignin. These materials are of null nutritional value for humans but are considered of high potential for energy use [8,9]. An example of lignocellulosic biomass in Panama is the Saccharum spontaneum, known locally as "Paja Canalera" or "Paja Blanca".

Saccharum spontaneum, is a perennial herbaceous species of Asian origin. It is not known with certainty how it was introduced to Panama. One version indicates that it was introduced to the Summit Experimental Garden during World War II, to save its genetic material from the damage of war (VON Linderman, 1985) as cited by [10]. Other versions indicate that it arrived to Panama through the transit of ships and cargoes from

Corresponding author: orlando.aguilar@utp.ac.pa 
affected countries during the $50 \mathrm{~s}$ and $60 \mathrm{~s}$ [10]. In its annual report on the economic and environmental valuation of Saccharum spontaneum in the Panama Canal Basin, the Tropical Agronomic Center for Research and Education (CATIE) indicates that this weed was introduced as slope stabilization coverage and to reduce erosion in the Panama Canal Basin [11]. Finally, it is concluded that it was introduced to Panama by the Zone Experiment Garden (Summit Garden) in the 1939 collection of copies of various varieties of sugarcane, in order to select, propagate and disseminate genetic materials free of diseases and improve the production of the sugar industry in Panama [10]. The Paja Canalera is an invasive, aggressive and easily dispersed weed (Figure 1), which has allowed it to invade agricultural fields, open spaces, deforested or clear forests, threatening the natural ecosystem, dominating the native species, and significantly reducing the agricultural production [10]. Currently, S. spontaneum has invaded large areas, especially, deforested land, areas altered by cut or fill, rocky, acidic soil and low fertility soils, limiting the growth of other species. These areas are subject to forest fires during the dry season, becoming a social and environmental problem throughout the country, but mainly in the Panama Canal Basin [12,13]. This weed is ranked among the 12 most important quarantine weeds in the world [14].

Due to its biological qualities, the Paja Canalera can be a promising biomasic resource from the energy point of view, which would be transforming a national ecological problem into a business opportunity, contributing to the diversification of the energy matrix and strengthening national energy autonomy. Currently there is technology that can be adapted for the energy use of this herbaceous species, and among these technologies, biomass gasification can be mentioned. Gasification is a thermochemical process in which a solid fuel is transformed into a gaseous fuel (syngas) through a series of reactions that occur at certain temperatures in the presence of an oxidizing agent. The gas produced can be used as raw material to produce chemical compounds or as fuel in internal or external combustion equipment to generate heat or power $[15$, $16]$.

The objective of this research is to evaluate the potential of the use of Saccharum Spontaneum as a renewable energy resource to produce electrical energy in Panama, through gasification.

\section{Materials and Methods}

\subsection{Sampling}

This study has two stages, in the first one, a sampling of $S$. spontaneum was carried out for the physicochemical characterization of the material. An estimation of the available energy potential was made based on these results and plant coverage in the lands invaded by this weed. In the second stage of the study, another sample of the material was carried out with the intention of conducting pilot gasification tests in the installed reactor.
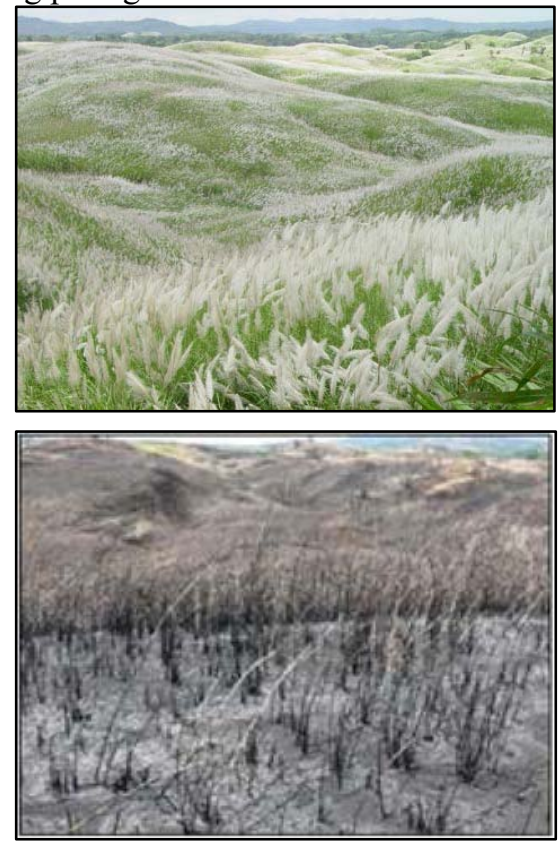

Fig. 1. Extensions of land infested with straw and exposed to forest fires [10].

The first sampling began with the selection of the biomass collection sites in their natural and wild state. The study was delimited to the Panama Canal Hydrographic Basin (CHCP), the "Plant Cover and Land Use Report of the Panama Canal Hydrographic Basin, 2013" [17] was used. The areas covered by $S$. spontaneum were filtered from the cartographic material, and based on the accessibility of the areas, but not near to roads with a lot of vehicular or pedestrian flow, ten areas covered by this weed were selected. From those ten areas, four sampling sites were finally randomly selected. In each site, an area of $4 \mathrm{~m}^{2}(2 \mathrm{~m} \times 2 \mathrm{~m})$ was delimited and all the vegetative material in the area was cut with a machete. Table 1 shows the coordinates of the sampling sites. Sampling was conducted during the rainy season, and at each site, the height of the plants was recorded in the four corners and in the center of the collection square.

Table 1. Sampling sites during stage 1.

\begin{tabular}{|c|c|c|}
\hline $\begin{array}{c}\text { Sampling } \\
\text { sites }\end{array}$ & Coordinates & Location \\
\hline Site 1 & $\begin{array}{l}9^{\circ} 12^{\prime} 54.7^{\prime \prime} \mathrm{N} \\
79^{\circ} 9^{\prime} 44.62^{\prime} \mathrm{O}\end{array}$ & $\begin{array}{l}\text { Nuevo Caimitillo, } \\
\text { Chilibre, Panamá }\end{array}$ \\
\hline Site 2 & $\begin{array}{l}9^{\circ} 9^{\prime} 44.622^{\prime \prime} \mathrm{N} \\
79^{\circ} 33^{\prime} 13.18^{\prime} \mathrm{O}\end{array}$ & $\begin{array}{l}\text { Los Pinos, Chilibre, } \\
\text { Panamá }\end{array}$ \\
\hline Site 3 & $\begin{array}{l}9^{\circ} 9^{\prime} 30.7^{\prime \prime N} \\
79^{\circ} 37^{\prime} 46.3 " \mathrm{O}\end{array}$ & $\begin{array}{l}\text { Chilibre Centro, } \\
\text { Chilibre, Panamá }\end{array}$ \\
\hline Site 4 & $\begin{array}{l}9^{\circ} 11^{\prime} 6.6 " \mathrm{~N} \\
79^{\circ} 33^{\prime} 51.1 " \mathrm{O}\end{array}$ & $\begin{array}{l}\text { Calzada Larga, } \\
\text { Caimitillo, Panamá }\end{array}$ \\
\hline
\end{tabular}

Since there was no significant difference in the physicochemical properties of the material between the sampling sites, the second sampling was performed in a place independent from the previous ones, as shown in Figure 2. In both samples of $S$. spontaneum, it was measured the length (with a retractable tape measure) 
and basal diameter (with vernier calipers Carrera Precision model CP9806-TF) of the collected plants. Finally, all the material was placed in bags and transported in a vehicle to the laboratory.

\subsection{Sample preparation}

This report only presents the analysis performed on the stems of the collected plants. To obtain the stems and separate the fraction of the leaves, a fair cut was made on the last nodule of the stem of each plant. The fraction of the stems was chopped, to decrease and standardize the particle size, using a Trapp chopper machine model TRF 300 Super, Brazil. The blade spacing was adjusted to approximately $10 \mathrm{~mm}$. All chopped material was weighed using a Rice Lake Weighing Systems Survivor CW-80 scale $(30 \mathrm{~kg} \pm 0.01 \mathrm{~kg})$. Then the biomass yield was determined on a wet basis per $\mathrm{m}^{2}$. Subsequently, all the material was placed on tarpaulins on the floor and was air dried by indoor natural ventilation.

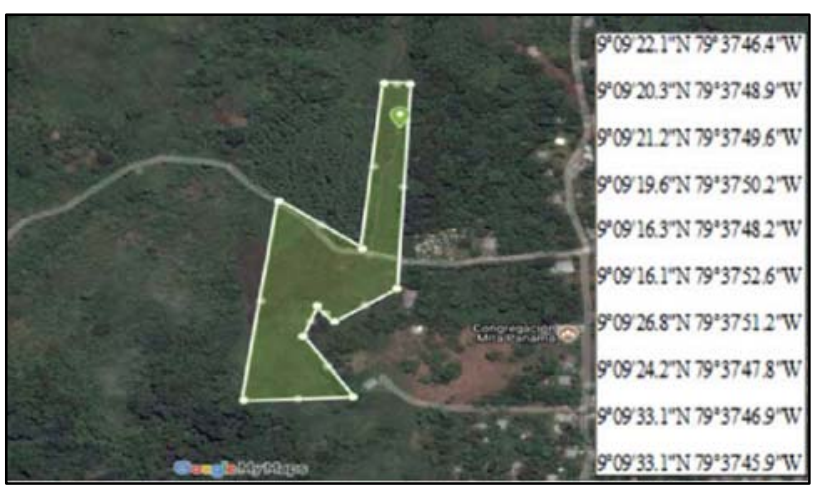

Fig. 2. Sampling polygon in the second stage of the study

\subsection{Physical-chemical properties}

The tests for the physicochemical properties of $S$. Spontaneum were made to different parts of the plants, such as trunk alone, leaves and whole plant. Bulk density was determined based on ASTM E873-82 [18]. The proximate analysis was performed based on ASTM E1757 [19]. The humidity was determined by a moisture balance (DBS 60-3, KERN \& SOHN GmbH, Germany). The ash content was determined based on ASTM E1755 [20]. Volatile Material was determined based on ISO 18123: 2015 [21]. A muffle furnace (Thermolyne model 47900) was used, with a maximum temperature of $1,200^{\circ} \mathrm{C}$ and an analytical balance (Mettler Toledo model MS $304 \mathrm{~S}$ ) with a maximum capacity of $320 \mathrm{~g}$ and sensitivity of $0.1 \mathrm{mg}$. The higher heating value (HHV) was determined by an isoperibolic calorimeter (LECO model AC500), according to ASTM D5865-13 and EN 14918: 2009 [22, 23].

\subsection{Pilot gasification tests for S. spontaneum}

Different runs of gasification of the dry material $(12 \%$ moisture by volume) were performed with air under ambient conditions as a gasifying agent. Various physical treatments of the biomass were tested, considering the whole plant (stem and leaves), only stems, crushed material, chopped, pelletized, etc., as shown in Table 2. It was also tested with different volumetric air flow rates and the resulting syngas was characterized by a Syngas infrared analyzer (Gas Analyzer Model Gasboard-3100P, Hubei Cubic-Ruiyi Instrument Co. China).

Table 2. Physical treatments tested in gasification.

\begin{tabular}{cl}
\hline Treatment & \multicolumn{1}{c}{ Description } \\
\hline TI & S. spontaneum finely crushed \\
\hline T2 & $\begin{array}{l}\text { Mixture of S. spontaneum both crushed } \\
\text { and fragmented }\end{array}$ \\
\hline T3 & S. spontaneum in fragments \\
\hline T4 & S. spontaneum coarse crushed \\
\hline T5 & S. spontaneum pelletized \\
\hline T6 & $\begin{array}{l}\text { S. spontaneum pelletized with a bamboo } \\
\text { thermal bed }\end{array}$ \\
\hline T7 & $\begin{array}{l}\text { Mixture of S. spontaneum pelletized and } \\
\text { crushed }\end{array}$ \\
\hline T8 & $\begin{array}{l}\text { S. spontaneum crushed with a wood } \\
\text { thermal bed }\end{array}$ \\
\hline T9 & \begin{tabular}{l} 
S. spontaneum in fragments (only stems) \\
\hline
\end{tabular} \\
\hline
\end{tabular}

\section{Results and discussion}

\subsection{Physicochemical properties and energetic potential of the S. spontaneum.}

Biomass weights and yields obtained for each site are shown in Table 3. It is important to mention and consider that the composition by weight of the straw collected may vary according to the time of year and according to the parts of the plant to be evaluated. At this stage of the project, given the very low energy density of the leaves, it was considered to evaluate the energy generated by gasification only of the stems of $S$. spontaneum. It is observed that the average yield of the stems resulted $3.7 \pm 1.5 \mathrm{~kg}_{\mathrm{bh}} / \mathrm{m}^{2}$, with values ranging from 2.0 to $5.6 \mathrm{~kg} / \mathrm{m}^{2}$. In some sites the material was relatively young (site 1), so it was observed that the variation in the amount of biomass found per site depends on the degree of plant maturity as well as soil physical conditions.

Table 3. Collected Saccharum spontaneum and biomass yield per sampling site.

\begin{tabular}{|c|c|c|c|c|}
\hline \multirow{2}{*}{ Biomass } & \multicolumn{4}{|c|}{$\begin{array}{l}\text { Weight }\left(\mathbf{k g}_{\mathrm{bh}}\right) / \\
\text { Sampling sites }\end{array}$} \\
\cline { 2 - 5 } & $\mathbf{1}$ & $\mathbf{2}$ & $\mathbf{3}$ & $\mathbf{4}$ \\
\hline Whole fresh plant & 11.8 & 32 & 23.7 & 15.7 \\
\hline Total stems & 8.0 & 22.2 & 16.7 & 11.5 \\
\hline Dead stems & 1.7 & 5.9 & 1.2 & 4.6 \\
\hline Surface área & \multicolumn{4}{|c|}{$4.0 \mathrm{~m}^{2}$} \\
\hline Average biomass yield for whole plant & \multicolumn{3}{|c|}{$5.2 \pm 2.2\left(\mathrm{~kg} / \mathrm{m}^{2}\right)_{\text {bh }}$} \\
\hline Average biomass yield for total stems & \multicolumn{3}{|c|}{$\mathbf{3 . 7} \pm 1.5\left(\mathrm{~kg} / \mathrm{m}^{2}\right)_{\mathrm{bh}}$} \\
\hline Average biomass yield for dead stems & $\mathbf{0 . 8} \pm 0.6\left(\mathrm{~kg} / \mathrm{m}^{2}\right)_{\mathrm{bh}}$ \\
\hline Mass ratio dead stems/total stems & \multicolumn{3}{|c|}{$0.80 / 3.7=\mathbf{2 1 . 6 2}$} \\
\hline
\end{tabular}


Air-drying tests show that biomass reaches its lowest surface moisture content in 23 days, with a daily weight loss of $1 \%$, under ambient temperature and relative humidity conditions of $28.2^{\circ} \mathrm{C}$ and $81 \%$, respectively. Water content of $S$. spontaneum was measured by site and for the different parts of the plant such as whole fresh plant, only fresh stems, and for the fraction of dead stems that were present in the sampling sites. Biomass water content was calculated as external humidity, inherent humidity, and total humidity, Table 4.

Table 4. Water content of $S$. spontaneum.

\begin{tabular}{|c|c|c|c|c|c|}
\hline \multirow{3}{*}{ Sample fraction } & \multicolumn{5}{|c|}{ Sampling sites / } \\
\hline & 1 & 2 & 3 & 4 & Average \\
\hline & \multicolumn{5}{|c|}{ External humidity (\% m/m) } \\
\hline Whole fresh plant & 67 & 56 & 53 & 59 & $59 \pm 6$ \\
\hline Only fresh stems & 70 & 60 & 59 & 69 & $64 \pm 6$ \\
\hline \multirow[t]{3}{*}{ Dead stems } & 23 & 2 & 34 & 31 & $23 \pm 14$ \\
\hline & \multicolumn{5}{|c|}{$\begin{array}{c}\text { Average inherent and total humidity } \\
\text { (\% mass/mass) }\end{array}$} \\
\hline & \multicolumn{3}{|c|}{ Inherent } & \multicolumn{2}{|c|}{ Total } \\
\hline Whole fresh plant & \multicolumn{3}{|c|}{11.78} & \multicolumn{2}{|c|}{68.24} \\
\hline Only fresh stems & \multicolumn{3}{|c|}{11.37} & \multicolumn{2}{|c|}{31.75} \\
\hline Dead stems & \multicolumn{3}{|c|}{11.68} & \multicolumn{2}{|c|}{60.35} \\
\hline
\end{tabular}

A bulk density of $110 \mathrm{~kg}_{\mathrm{bsa}} / \mathrm{m}^{3}$ was determined for the stems of $S$. spontaneum, while the apparent density of the entire plant is reported as $60 \mathrm{~kg}_{\mathrm{bsa}} / \mathrm{m}^{3}$, considering the weight of the plants after the loss of moisture by drying at air (bsa). We report a lower heating value of the stems equal to $19.18 \mathrm{MJ} / \mathrm{kg}_{\mathrm{bs}}$. The ash content resulted $3.29 \%$, it seems to be relatively high, but this is expected as it is an herbaceous species. The volatile material and the fixed carbon correspond to the energy fraction, so a high content of both components is favourable. The results indicate a low fixed carbon content $(13.93 \%)$, which disadvantages conversion by pyrolysis. It follows then, that combustion and gasification might be two appropriate pathways for the energy conversion of $S$. spontaneum. The proximate analysis and other physicochemical properties of the stems of $S$. spontaneum under wild growth conditions typical of the region, is shown in Table 5.

Table 5. Proximate analysis of S. spontaneum.

\begin{tabular}{|l|c|}
\hline \multirow{2}{*}{ Proximate Analysis } & $\begin{array}{c}\text { Only stems Composition } \\
\text { (m/m) on air dry basis } \\
\text { (bsa)) }\end{array}$ \\
\hline \%Ash bsa & $3.29 \%$ \\
\hline \%Volatile Material ${ }_{\text {bsa }}$ & $71.00 \%$ \\
\hline \%Fixed Carbon bsa & $13.93 \%$ \\
\hline \multirow{2}{*}{ Bulk density bsa } & $110 \mathrm{~kg}_{\text {bsa }} / \mathrm{m}^{3}$ (only stems) \\
\cline { 2 - 2 } & $60 \mathrm{~kg} / \mathrm{m}^{3}$ (whole plant) \\
\hline Lower Heating Value & $19.18 \mathrm{MJ} / \mathrm{kg}_{\mathrm{bs}}$ (only stems) \\
\hline
\end{tabular}

Under the conditions of this study, we report an energy potential of $536.5 \mathrm{GWh}$. This estimated energy potential, is based on a total coverage surface area of
$6932 \mathrm{ha}$, a total stems yield of $3.7 \mathrm{~kg} / \mathrm{m}^{2}{ }_{\text {bh }}$, with a total average stems humidity of $60.35 \%$ (external and inherent humidity ${ }_{\mathrm{bh}}$ of $64 \% ; 11.78 \%$ and $23 \% ; 11.37 \%$, for fresh and dead stems, respectively), and a mass ratio of dead stems to total stems of $21.6 \%$. This energy potential was estimated based on the process of only stems of $S$. spontaneum.

Based on this energy potential and considering a power plant operating only during the dry season (January to March), with an overall conversion efficiency of $20 \%$ [24], and $75 \%$ plant availability factor, a power plant of $66 \mathrm{MW}$ based on gasification of $S$. spontaneum can be installed with these renewable resource.

Table 6. Results of the pilot gasification tests of S. spontaneum.

\begin{tabular}{|c|c|c|c|c|c|c|}
\hline Treatment & $\begin{array}{c}\text { Air Flow } \\
\text { (lpm) }\end{array}$ & $\% \mathrm{H}_{2}$ & $\% \mathrm{CO}$ & $\% \mathrm{CH}_{4}$ & $\% \mathrm{CO}_{2}$ & $\begin{array}{c}\text { LHV } \\
\left(\mathbf{M J} / \mathbf{m}^{3}\right)\end{array}$ \\
\hline TI & 8.67 & $4^{1.5}$ & $2^{0.0}$ & $1^{0.0}$ & 0.18 & 0.17 \\
\hline $\mathbf{T 2}$ & 10.61 & $\begin{array}{l}0.2 \\
1\end{array}$ & $3^{1.6}$ & $\begin{array}{l}0.2 \\
6\end{array}$ & 9.14 & 0.33 \\
\hline T3 & 10.61 & $3^{1.0}$ & 4.0 & $\begin{array}{l}0.9 \\
7\end{array}$ & 11.83 & 1.06 \\
\hline T4 & 8.67 & $3^{0.7}$ & $2^{3.0}$ & $5^{0.5}$ & 7.27 & 0.71 \\
\hline T5 & 8.67 & $2^{1.3}$ & $7^{3.3}$ & $3^{0.5}$ & 4.71 & 0.81 \\
\hline T6 & 10.61 & $5^{2.4}$ & $3^{4.8}$ & $6^{0.6}$ & 9.95 & 1.31 \\
\hline T7 & 25.07 & $1^{1.7}$ & $\begin{array}{l}4.3 \\
9\end{array}$ & $\begin{array}{l}0.7 \\
1\end{array}$ & 9.73 & 1.2 \\
\hline T8 & 27.00 & $4^{1.6}$ & $8^{4.0}$ & $\begin{array}{l}0.9 \\
7\end{array}$ & 6.49 & 1.26 \\
\hline T9 & 28.93 & $2^{3.1}$ & 7.8 & 2.9 & 12.09 & 2.24 \\
\hline
\end{tabular}

\subsection{Pilot gasification tests for S. spontaneum}

In the gasification tests, different trials were carried out under different physical conditions of the biomass as well as the air flow entering the reactor. The objective was, while testing the installed reactor, generate a matrix of results able to show the best combination of variables that lead to the highest concentrations of $\mathrm{H}_{2}, \mathrm{CO}$ and $\mathrm{CH}_{4}$ in the resulting syngas, Table 6 .

During the runs of the different treatments it was observed that the crushed $S$. spontaneum was not able to raise and sustain the required temperature in the reactor. This may be a consequence of low bulk density of this material, which led to the implementation of various mixtures of the material, trying to increase its bulk density. This led to the addition of bamboo and wood, as bed in the combustion zone of the reactor, trying to sustain high temperatures, facilitating the gasification reaction. It is then observed that as the biomass bulk density within the reactor increases, the concentration of the syngas components $\left(\mathrm{H}_{2}, \mathrm{CO}\right.$, and $\left.\mathrm{CH}_{4}\right)$ of interest, 
improves. In the same way, we also increased the volumetric air flow rate, resulting in the best gasification condition, the one established as T9 treatment.

\section{Conclusions}

- S. pontaneum has thermophysical properties suitable for thermochemical biomass conversion pathways, specially combustion and gasification.

- S. spontaneum is a wild species that has become an ecological and economic problem in Panama but it has the opportunity to become an energy crop with a potential, in the case of stems, of $536.5 \mathrm{GWh}$, which corresponds to a power plant of $66 \mathrm{MW}$ capacity working during the dry season (January to March).

- The results of the pilot tests are inconclusive yet, since they require replication; however, the T9 treatment that consisted of gasification of only stems of $S$. spontaneum, with a volumetric air flow rate greater than 25 liters per minute, seems to be the best option of gasification of $S$. spontaneum, at the environmental conditions in the Republic of Panama.

\section{Acknowledgements}

This work has been carried out with the financing of the National Secretariat of Science, Technology and Innovation (SENACYT) of Panama, Grant $N^{\circ}$ 2016-4-IDDS15-083 and by the Universidad Tecnológica de Panamá. Technical support from the Laboratory of Industrial Analysis and Environmental Sciences (LABAICA), the Center for Agroindustrial Production and Research (CEPIA), and the Mechanical Engineering Department (FIM) of the Universidad Tecnológica de Panamá, for providing us with its facilities, equipment, time and knowledge in the development of this work is acknowledge. Special thanks to Mr. Ernesto Escobar, Mrs. Alma Espinosa, Mr. Leopoldo Manso, and Dr. Arthur James for their support. Finally, the colaboration of Mr. Arturo Cerezo from the Environmental Division of the Panama Canal Authority is greatly appreciated.

This work is under development as part of the research interest of the Research Group on Renewable Energy and Environment (GIERA) at UTP.

\section{References}

1. D. L. Klass, Biomass for Renewable Energy, Fuels, and Chemicals. Elsevier, (1998).

2. P. A. Breeze, Power generation technologies.(2014).

3. R. G. Boundy, S. W. Diegel, L. L. Wright, y S. C. Davis, «Biomass Energy Data Book: Edition 4», Oak Ridge, TN (United States). (2011).

4. P. McKendry, «Energy production from biomass (part 2): Conversion technologies», Bioresour. Technol., vol. 83, n.o 1, pp. 47-54. (2002).

5. C. L. Williams, A. Dahiya, y P. Porter, «Introduction to Bioenergy», en Bioenergy, A. Dahiya, Ed. Boston: Academic Press, pp. 5-36 (2015).

6. B. Rivas, G. Zúñiga, J. Sáenz, S. Guerrero, A. Segovia y H. Morales. Perspectivas de obtención de energía renovable de la biomasa del estiércol del ganado lechero en la región Centro-Sur de Chihuahua. Revista Mexicana de Agronegocios, vol. 16, no 30, pp. 872-885, (2012).

7. P. Basu, Biomass gasification, pyrolysis and torrefaction: practical design and theory. Academic Press, (2013).

8. J. Cai et al., «Review of physicochemical properties and analytical characterization of lignocellulosic biomass», Renew. Sustain. Energy Rev., vol. 76, n.o March, pp. 309-322, (2017).

9. T. L. T. Nguyen, J. E. Hermansen, y R. G. Nielsen, «Environmental assessment of gasification technology for biomass conversion to energy in comparison with other alternatives: the case of wheat straw», J. Clean. Prod., vol. 53, pp. 138-148. (2013).

10. Cerezo, Arturo. "Antecedentes del origen y objetivo de la introducción de la maleza paja blanca (Saccharum spontaneum L.) a Panamá”. Autoridad del Canal de Panamá. Departamento de Ambiente, Agua y Energía. División de Ambiente. Sección de Manejo de Cuenca. (2010).

11. CATIE, 2000. Centro Agronómico Tropical de Investigación y enseñanza (CATIE). Informe anual 2000. Valoración Económica y Ambiental de "Paja Blanca" (Saccharum spontaneum) en la Cuenca del Canal de Panamá. Turrialba, Costa Rica. (2001).

12. B. W. Hammond, «Saccharum spontaneum (Gramineae) in Panama», J. Sustain. For., vol. 8, n.o 3-4, pp. 23-38, sep. (1999).

13. K. Saltonstall y G. D. Bonnett, «Fire promotes growth and reproduction of Saccharum spontaneum (L.) in Panama», Biol. Invasions, vol. 14, n.o 12, pp. 2479-2488, dic. (2012).

14. Palencia, Ixchel. Problemas socioeconómicos y ambientales asociados a la paja canalera (Saccharum spontaneum) en la Cuenca del Canal de Panamá. Tesis Mag. Sc., Turrialba, Costa Rica. CATIE, 81p. (2000).

15. Forero Rodríguez C., Gerardo Gordillo Ariza, "Adiabatic Gasification of Sugarcane Bagasse Using Air-Steam". Revista de Ingeniería no. 33. Scielo, ISSN 0121-4993. Bogotá, Colombia. (2011).

16. Arteaga-Pérez Luis, Casas Yannay, Cabrera Jagni, and Rodríguez Lizet. "Gasificación de biomasa para la producción sostenible de energía. Revisión de las tecnologías y barreras para su aplicación", AfinidadBarcelona. 72(570):1. (2015).

17. División de Ambiente de la Autoridad del Canal de Panamá (ACP). Informe de Cobertura Vegetal y Uso de Suelo de la Cuenca Hidrográfica del Canal de Panamá. Panamá, (2013).

18. ASTM E873-82, «Standard Test Method for Bulk Density of Densified Particulate Biomass Fuels.» (2013).

19. ASTM E1757-01, «Standard Practice for Preparation of Biomass for Compositional Analysis». (2015).

20. ASTM E1755-01, «Standard Test Method for Ash in Biomass». (2015).

21. ISO 18123:2015, «Solid biofuels - Determination of the content of volatile matter». (2015). 
22. EN 14918:2009, «Solid biofuels - Determination of calorific value». (2009).

23. ASTM D5865-13, «Standard Test Method for Gross Calorific Value of Coal and Coke». (2013).

24. M. R. Nouni, S. C. Mullick, y T. C. Kandpal, «Biomass gasifier projects for decentralized power supply in India: A financial evaluation», Energy Policy, vol. 35, n.o 2, pp. 1373-1385. (2007). 